\title{
Risk/benefit evaluation of traditional and novel formulations for snacking: Acrylamide and furfurals as process contaminants
}

\author{
M. Mesías, C. Delgado-Andrade, F.J. Morales \\ Institute of Food Science, Technology and Nutrition, ICTAN-CSIC, Madrid 28040, Spain
}

\begin{abstract}
Novel alternatives for snacking contain ingredients such as pseudo-cereals, roots or legumes, which offer health related benefits to consumers. Alternative technological processes have been introduced within the snack industry that encompass valued sensorial characteristics and improve nutritional quality of the new formulations. However, the impact of the novel formulations on the exposure to process contaminants must also be carefully evaluated. The present study investigated the occurrence of acrylamide, hydroxymethylfurfural (HMF) and furfural in novel formulations and compared this with that seen in traditional snacks. Some novel snacks presented high levels of acrylamide, specifically chips with a potatobased dough (1252-1393 $\mu \mathrm{g} / \mathrm{kg}$ ) and chips made from other vegetables (carrot chips: $958 \mu \mathrm{g} / \mathrm{kg}$; beet chips: $908 \mu \mathrm{g} / \mathrm{kg}$ ). These samples demonstrated concentrations that exceeded those observed in traditional snacks (44-67l $\mu \mathrm{g} / \mathrm{kg})$. The average values of HMF and furfural in the novel formulations were also significantly higher than traditional ones (approximately 2.5- and 3-fold, respectively). The snack manufacturing industry should consider the nutritional and sensorial improvements gained through the application of alternative technological process or the addition of health-promoting ingredients in the design of innovative snacks. This must be considered alongside toxicological aspects which reduce the content of process contaminants.
\end{abstract}

KEYWORDS: Traditional snacks, Acrylamide, Hydroxymethylfurfural, Furfural, Exposure, Food analysis, Food composition

\section{INTRODUCTION}

The consumption of snacks has increased in recent decades, becoming part of the dietary habits and lifestyle of many consumers (MAPAMA, 2017). Consumer demand for novel products that satisfy convenience needs and sensory and health trends has led food companies to modify the composition of traditional snacks. Such snacks now offer a healthier formulation that is low-calorie, low-fat, low-carbohydrate, low-sodium and rich in fiber and vitamins. Novel products are formulated with alternative ingredients such as pseudo-cereals, roots, legumes, and others. Many such products have emerged recently from the food market with the aim of increasing nutritional value and improving health-promoting properties of foodstuffs (Niva, 2007). Their formulation combines the complexity of satisfying the changing tastes and expectations of different consumers, with the search for unique products that provide nutritional characteristics and greater market value (Bartelme, 2016). The development of these types of snacks is, therefore, an emerging and innovative aspect of the sector.

Extrusion, frying and baking are the main processing techniques used worldwide in the development of snack products. Extrusion has been used extensively in the production of snacks due to its ease of operation and ability to produce a variety of textures and shapes which appeal to consumers (Brennan et al., 20I3). Frying imparts flavor, taste, color and crispness in the fried foods (Farkas et al., 1996; Krokida et al., 200I), whereas baking produces valuable sensorial characteristics with a crisp texture but a lower fat content (Han et al., 2010). Further alternative methodologies to be employed by the snack industry include ultrasoundosmotic dehydration prior to frying (Dehghannya and Abedpour, 20I8), vacuum frying (Dueik et al., 20l0), 
oven toasting (Nath and Chattopadhyay, 2007) and injection with carbon dioxide gas during the extrusion process (Masatcioglu et al., 2014). These alternatives enable the properties of the novel formulations for snacking to be modified, obtaining new textural and sensory properties.

Novel formulations and innovative technologies have the potential to improve the nutritional profile and the sensorial quality of snacks. However, the use of novel ingredients within the recipe and the application of alternative technological processes may also affect the formation of process contaminants including acrylamide and emerging process contaminants, such as hydroxymethylfurfural (HMF) and furfural. Process contaminants, and more precisely heat-induced process contaminants, form as a result of the thermal treatments applied during processing. These compounds are essentially produced by the Maillard reaction, initiated by carbohydrates but also by carbonyls generated from the lipid oxidation (Zamora and Hidalgo, $20 \mathrm{II})$. Acrylamide is generated as a result of the reaction between asparagine and reducing sugars, which are its main precursors. The European Food Safety Agency (EFSA) has identified the presence of acrylamide in food as a possible public health concern due to its relation with different types of cancer. This obviates the need for continued efforts to reduce exposure to this metabolite (EFSA, 2015). HMF and furfural are formed as intermediate products of the Maillard reaction. Furthermore, HMF is generated from the caramelization of sugars at high temperatures (Morales, 2008). With regards to HMF, animal studies have identified its biotransformation into the genotoxic and mutagenic metabolite, sulphoxymethylfurfural (Høie et al., 20I5; Pastoriza de la Cueva et al., 2017). Further, furfural may lead to hepatotoxicity (EFSA, 2005).

The Commission Regulation (EU) 2017/2158 establishing mitigation measures and benchmark levels for the reduction of the presence of acrylamide in food considers French fries (ready-to-eat), potato crisps from fresh potatoes and from potato dough, and other potato products from potato dough (European Commission, 2017). However, other snack formulations are not considered by the regulation. The objective of the present work was to evaluate the levels of acrylamide, HMF and furfural in novel snack formulations, or so-called healthy snacks, and to compare these with traditional snack formulations. This prospective study aims to consider the risk/benefit of these innovative products, assessing if they are a healthier option relative to traditional ones, not only in nutritional but also in toxicological terms.

\section{MATERIALS AND METHODS}

\section{I Reagents and chemicals}

Potassium hexacyanoferrate (II) trihydrate (98\%, Carrez-I) and zinc acetate dehydrate (>99\%, Carrez-II) were obtained from Sigma (St. Louis, USA). ${ }^{13} \mathrm{C}_{3}$-labelled acrylamide ( $99 \%$ isotopic purity) was obtained from Cambridge Isotope Laboratories (Andover, MA, USA). Formic acid (98\%), D(+)-Glucose and methanol (99.5\%) were acquired from Panreac (Barcelona, Spain). Deionized water was obtained from a Milli-Q Integral 5 water purification system (Millipore, Billerica, MA, USA). Reversed-phase Oasis-HLB cartridges (30 mg, I mL) were purchased from Waters (Milford, MA, USA). Syringe filter units ( $0.45 \mu \mathrm{m}$, cellulose) were purchased from Análisis Vínicos (Tomelloso, Ciudad Real, Spain). All other chemicals, solvents and reagents were of analytical grade.

\subsection{Samples}

Snacks $(n=77)$ were purchased from various Spanish supermarkets in May 2017. Samples were classified as traditional snacks $(n=46)$ or novel formulation snacks $(n=3 I)$. Classification was based on commercial claims regarding the health profile of the product and the producers description of its composition. Sampling included the largest number of alternatives found in the market and avoided the duplication of products belonging to the same category, for instance, savory snacks made from the same formulation. The aim was 
to evaluate a wide and representative scenario of snacking choices and identify the degree of variability in their formulations and processing. The sample examined is representative in the context of the Spanish industry but could also be extrapolated to the European market since most of the commercial brands are present in EU countries. Samples were grouped according to their main ingredient such as cereal, root or tuber, legume and others. The major and innovative ingredients for each sample are detailed in the Supplementary Material (Annex I, 2) (quinoa, oatmeal, spelt, soybean, carrot, parsnip, beet, cassava, lentil, chickpea, banana and seaweed). The presence of innovative ingredients provided the criteria by which snacks were classified as novel formulations. For each sample, the whole bag was mixed and grounded to assure a homogeneous distribution of potential hotspots. Then a portion of 50-100 g was vacuum packaged and stored under light protection at $4{ }^{\circ} \mathrm{C}$ until analysis.

\subsection{LC-ESI-MS-MS determination of acrylamide}

Acrylamide was determined as described by Mesias and Morales (2015). The accuracy of this method for potato crisps has been recently demonstrated in three proficiency tests launched by the Food Analysis Performance Assessment Scheme (FAPAS) program, yielding a z-score of 0.2 (Test 3065, May-June 2016), 0.2 (Test 307I, Feb-March 2017) and - 0.3 (Test 3080, Feb-March 2018). Precision (reproducibility) was lower than 10\%, and recovery between 84 and 109\%. The limit of the quantitation was set at $20 \mu \mathrm{g} / \mathrm{kg}$. Analyses were performed in duplicate and results were expressed as $\mu \mathrm{g} / \mathrm{kg}$ of product.

\subsection{Determination of HMF and furfural}

HMF and furfural determinations were based on the method previously reported by Rufián-Henares et al. (2009). Quantitation was conducted with a Shimadzu HPLC system, as previously described by Mesias et al. (2015). Chromatographic separation was carried out on a Mediterranean Sea ODS-2 $(250 \times 4.0 \mathrm{~mm}, 5 \mu \mathrm{m}$, Tecknokroma, Barcelona, Spain). The mobile phase was an acetonitrile and water mix $(5 \mathrm{~mL} / 100 \mathrm{~mL})$, with a flow rate of $\mathrm{I} \mathrm{mL} / \mathrm{min}$ under isocratic conditions. The total running time was $20 \mathrm{~min}$, the UV detector was set at $280 \mathrm{~nm}$ and $20 \mu \mathrm{L}$ of the extract was injected. HMF and furfural were quantified using the external standard. The limit of quantification was set at 0.3 and $0.2 \mathrm{mg} / \mathrm{kg}$ for HMF and furfural, respectively. Analyses were done in duplicate and results were expressed as $\mathrm{mg} / \mathrm{kg}$ sample.

\subsection{Food consumption data and exposure}

Dietary exposure to acrylamide, HMF and furfural within the different categories of snacks was estimated by considering data for total per capita consumption of snack (6.43 kg/person/year), as established by the Spanish Association of snack manufacturers (AFAP, 2015) and the percentage of consumption assigned to each type of product (22\% of the total, excluding French fries and nuts). An average adult body weight of 70 $\mathrm{kg}$ was assumed.

\subsection{Statistical Analysis}

Statistical analyses were performed using SPSS version 23 (SPSS, Chicago, IL). Data were expressed as mean \pm standard deviation (SD). Student's t-test was used to identify the overall significance of differences between the two groups. Analyses were performed of the process contaminants identified in the tested snacks (traditional group versus novel formulations). Differences were considered to be significant at $\mathrm{p}<$ 0.05. Relationships between the different measured parameters were evaluated using Spearman correlation coefficients at the $p<0.05$ confidence level. Correlations were also performed between the aforementioned parameters and the nutrient content (as provided on the product labels).

\section{RESULTS AND DISCUSSION}




\section{I Nutritional composition of snacks}

Nutritional composition of traditional (Table I) and novel (Table 2) snacks was described according to information provided by the manufacturer. The energy contained in traditional snacks (393-567 kcal/ $100 \mathrm{~g}$ ) and novel formulations (364-508 kcal/l00 g) was not found to be significantly different. The protein, carbohydrate and sugar content was similar between groups, with two exceptions: i) pork rinds contained the highest level of protein $(70 \mathrm{~g} / 100 \mathrm{~g}$ ) but was void of carbohydrate, and ii) root-based chips contained the ighest level of sugars $(32 \mathrm{~g} / 100 \mathrm{~g})$. Novel snacks presented a higher fiber content (with values up to 14.3 $\mathrm{g} / \mathrm{l} 00 \mathrm{~g}$ ) and a lower fat content (with values up to $29 \mathrm{~g} / 100 \mathrm{~g}$ ), when compared to traditional snacks (values up to $6.9 \mathrm{~g} / 100 \mathrm{~g}$ for fiber and up to $35.5 \mathrm{~g} / 100 \mathrm{~g}$ for total fat). Differences in the composition of snacks were more evident with regards to saturated fatty acid content, with novel snacks not exceeding $4 \mathrm{~g} / \mathrm{l} 00 \mathrm{~g}$, except in the case of salty banana chips $(1 \mathrm{l} .3 \mathrm{~g} / \mathrm{l} 00 \mathrm{~g})$, and traditional snacks displaying values up to $18 \mathrm{~g} / \mathrm{l} 00$ g. Similarly, novel formulations presented lower salt content $(0.08-3.1 \mathrm{~g} / \mathrm{l} 00 \mathrm{~g})$ (Table 2$)$ in comparison to traditional snacks $(0.8-4.5 \mathrm{~g} / \mathrm{l} 00 \mathrm{~g})($ Table $\mathrm{I})$. In this sense, the formulation of novel snacks provides a nutritional tool for achieving public health recommendations and population salt reduction strategies aimed at addressing the associated burden of chronic disease (Jaenke et al., 20I7).

\subsection{Acrylamide levels in snacks}

Acrylamide levels in traditional snacks ranged from 44 to $671 \mu \mathrm{g} / \mathrm{kg}$, with a mean value of $194 \mu \mathrm{g} / \mathrm{kg}$ (Table 3 , Fig. I). These levels are in concordance with those reported by the Food and Drug Administration (FDA, 2006), EFSA (EFSA, 2015), and other authors when analyzing similar categories of snacks (Takatsuki et al., 2003; Zubeldia Lauzurica and Gomar Fayos, 2007; Daniali et al., 2010; Cheng et al., 20I2; Komthong et al., 2012; Shamla and Nisha, 20I4). The lowest acrylamide content in the traditional sample group was observed in cheese leaf chips $(44 \mu \mathrm{g} / \mathrm{kg})$ and cheese puffs $(48 \mu \mathrm{g} / \mathrm{kg})$. On the other hand, the highest acrylamide values were found in ketchup flavored snacks $(67 \mathrm{I} \mu \mathrm{g} / \mathrm{kg})$ and in cheese and ketchup flavored snacks $(660 \mu \mathrm{g} / \mathrm{kg})$ (Table 3). Most of the traditional snacks are cereal-based (mainly corn and wheat) and may or may not be mixed with potato. While the specific technological process applied to each product is unknown, traditional methods in the snack industry typically include deep-frying, extrusion, drying and baking (Riaz, 2016). The high temperatures applied during deep-frying and baking promote the formation of process contaminants. This has been well reported in cereal and potato-based products (Açar and Gökmen, 2009; Gökmen et al., 2006). In the case of extrusion, foods are directly cooked in the extruder at $140-180^{\circ} \mathrm{C}$. Upon leaving the extruder they are dried and shaped due to sudden decompression. Finally, they are toasted at temperatures as high as $330^{\circ} \mathrm{C}$ (Fast, 200I).

The acrylamide content of the alternative snacks ranged from none detected to $1393 \mu \mathrm{g} / \mathrm{kg}$. The mean content $(263 \mu \mathrm{g} / \mathrm{kg})$ was higher than that of traditional snacks $(194 \mu \mathrm{g} / \mathrm{kg})$, though differences were not statistically significant. Four samples displayed very high values for acrylamide (Fig. I): cereal, potato and soy

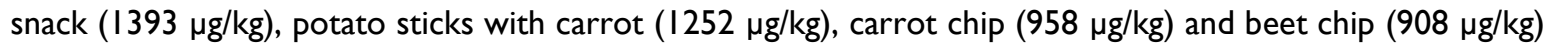
(Table 4). These findings support the need to examine contemporary formulations of food products using risk/benefit considerations. The search for healthier and more nutritious products to meet consumer demand has led snack manufacturers to use alternative technologies. In this respect, innovative treatments such as vacuum frying (Dueik et al., 2010), ultrasound-osmotic dehydration combined with the frying process (Dehghannya and Abedpour, 2018) and oven toasting at optimum process conditions (Nath and Chattopadhyay, 2007), have proven to be efficient in producing reduced-fat products. In addition, these novel snack formulations exhibit desirable quality attributes, preserve nutritional value and color properties, and improve the crispness and overall acceptability of products. However, modifications in the composition of the foodstuffs and the different processing conditions may also contribute to the generation of high 
amounts of process contaminants (Cheng et al., 2012; Stadler and Studer, 2017). An example of this is given by Mesias et al. (2016) who incorporated chia flour into biscuits. While nutritional properties of the biscuits were improved, acrylamide content was also higher in the new formulation. A higher acrylamide formation has also been reported in fried potato crisps embellished with dragon fruit extract (Cheng et al., 20l0). Despite improved antioxidant properties of the crisps, functional properties should be carefully considered alongside the risk/benefit, whereby increasing a benefit (antioxidant) should not increase a risk (process contaminants).

In June 2015, EFSA concluded that the presence of acrylamide in foods potentially increased the risk of developing certain types of cancer in all age groups (EFSA, 2015). Due to uncertainty surrounding the human health risk, exposure to acrylamide is a public health concern and a priority for the National Food Safety Authorities. Recently, the Directorate General for Health and Food Safety of the European Commission has established mitigation measures and updated benchmark levels for the reduction of acrylamide in food (European Commission, 2017). The benchmark levels target the main contributors of acrylamide in food. These include fried potato products, cereals, coffee and coffee substitutes, baby foods, and processed cereal based foods intended for infants and young children. The Commission Regulation established specific mitigation measures referring to French fries (ready-to-eat), potato crisps made from fresh potatoes and from potato dough, and other potato products made from potato dough. In the case of mixed dough, the reference value for potato dough is considered when potato is the major ingredient. The regulation does not yet include specific benchmark levels for snacks that are not potato dough-based. Reference values for cereal-based products (maximum $400 \mu \mathrm{g} / \mathrm{kg}$ excluding ginger bread) and potato products $(750 \mu \mathrm{g} / \mathrm{kg}$ ) are available that are based on their composition. In the traditional snack group, all samples formulated with potato exhibited acrylamide concentrations lower than the reference value. In contrast, two samples containing potato and pertaining to the novel snack group also showed levels higher than $750 \mu g / \mathrm{kg}$. As previously mentioned, these samples were potato sticks with carrot $(1252 \mu \mathrm{g} / \mathrm{kg})$ and snacks formulated with cereal, potato and soy (I393 $\mathrm{\mu g} / \mathrm{kg}$ ). Several variables directly affect acrylamide levels in potato products. These include the content of precursors in the fresh tuber (asparagine and reducing sugars), processing conditions and the final moisture (Elmore et al., 2005). Potatoes are a rich source of free asparagine $(2010-4250 \mathrm{mg} / \mathrm{kg}$ ) and reducing sugars $(97-2550 \mathrm{mg} / \mathrm{kg})$. Reducing the sugar content is a limiting factor of acrylamide formation in potato products (Becalski et al., 2004; Williams, 2005). Vegetables other than potatoes have a similar sugar and asparagine composition. Equivalent acrylamide formation during the thermal treatment could therefore be promoted. For example, levels of $515 \mu \mathrm{g} / \mathrm{kg}$ in fried pumpkin chips and $225 \mu \mathrm{g} / \mathrm{kg}$ in fried carrot chips (no other ingredients were present) have been recently reported by Mesias et al. (2018). In the present study, the acrylamide content in some of the vegetable chips (beet and carrot chips) were similar to those reported in French fries (Mesias and Morales, 2015) (Table 4).

Cereals contain lower levels of precursors of acrylamide compared with potato. Consequently levels of acrylamide are usually lower in cereal-based products (Granby et al., 2008). According to Cheng et al. (2012), the progression of acrylamide content among typically used bases for snack foods is rice flour<corn flour $<$ wheat flour<wheat/potato mixed flour<rice/potato mixed flour. In the present study, six samples in the traditional snacks group and two samples in the novel formulations group presented acrylamide concentrations higher than $400 \mu \mathrm{g} / \mathrm{kg}$. This exceeds the reference values recommended for all cereal-based products, apart from spices bread (European Commission, 2017). However, these concentrations are not only a product of the kind of cereal used, but result from the combination of all ingredients together with the processing conditions, which can also affect the formation of the contaminant. 
Amongst the innovative snacks, those including legumes in their formulation showed levels of acrylamide ranging from none detected to $40 \mathrm{I} \mu \mathrm{g} / \mathrm{kg}$ (mean value: $142 \mu \mathrm{g} / \mathrm{kg}$ ) (Table 4). On the other hand, the concentration observed in seaweed chips was very low $(43 \mu \mathrm{g} / \mathrm{kg})$, corroborating results reported by Cheng et al. (2012). These authors stated that the low level of acrylamide in this foodstuff was due to the absence of reducing sugars and asparagine.

Exposure to acrylamide within the Spanish population has been estimated according to data on total per capita consumption of snacks as established by the Spanish Association of snack manufacturers (AFAP, 20I5). In 2015 , snack consumption was $6.43 \mathrm{~kg} /$ person/year, with $22 \%$ being snacks that did not include nuts and potato chips. Assuming an average adult body weight (bw) of $70 \mathrm{~kg}$, exposure to acrylamide through the different groups of snacks ranges from 2.43 to $37.10 \mathrm{ng} / \mathrm{kg}$ bw/day for traditional snacks (mean: $10.77 \mathrm{ng} / \mathrm{kg}$ bw/day) and from 0.55 to $77.01 \mathrm{ng} / \mathrm{kg}$ bw/day for novel formulations (mean: $17.22 \mathrm{ng} / \mathrm{kg}$ bw/day) (Table 5). Both of these ranges are similar to those previously reported from potato crisps and potato chips in adult populations (Mojska et al., 2010; Sirot et al., 2012; Pugajeva et al., 2014; Mesias and Morales, 2015). Levels lower than $40 \mu \mathrm{g} / \mathrm{kg}$ bw/day are considered to describe tolerable daily intake (TDI) for neurotoxicity of acrylamide, while levels lower than $2.6-16 \mu \mathrm{g} / \mathrm{kg}$ bw/day have been associated with the development of some types of cancer (Tardiff et al., 2010). However, due to the carcinogenic properties of acrylamide, no safe levels can be established for this compound (FAO/WHO, 2010). The margin of exposure (MOE) for acrylamide in the different groups of snacks has also been calculated. MOE values for acrylamide were 28,783 and 18,002 for traditional and novel formulations, respectively, using the established benchmark doses (BMDLI0) $(310 \mu \mathrm{g} / \mathrm{kg}$ bw/day) found for mammary tumors in female rats. Similarly, MOE values of 16,716 (traditional snacks) and 10,452 (novel formulations) were obtained when comparing with the established BMDLIO (I80 $\mu \mathrm{g} / \mathrm{kg}$ bw/day) for Harderian gland tumors in male mice. According to the EFSA Scientific Committee on Contaminants in the Food Chain (CONTAM Panel), an MOE above 10,000 for a compound that is both genotoxic and carcinogenic is considered to be of low health concern (EFSA, 20I5).

\subsection{HMF and Furfural levels in snacks}

Content of HMF and furfural in the individual snacks is presented in Table 3 (traditional snacks) and Table 4 (novel snacks). An overall comparison between both groups is provided in Fig. 2 (HMF content) and Fig. 3 (furfural content). Results showed a high variability between traditional and novel snacks, and amongst the various categories (cereal-based, root/tubes-based, legumes, and other). HMF levels ranged from none detected to $91.30 \mathrm{mg} / \mathrm{kg}$ in traditional snacks (Table 3) and from 0.40 to $94.70 \mathrm{mg} / \mathrm{kg}$ in novel formulations (Table 4) (Fig. 2). Mean HMF content in traditional snacks $(7.00 \mathrm{mg} / \mathrm{kg}$ ) was significantly lower than that found in the innovative formulations $(18.52 \mathrm{mg} / \mathrm{kg})(p=0.042)$. Differences were more pronounced with regards to furfural content, where novel formulations exhibited significantly higher concentrations (2.53 $\mathrm{mg} / \mathrm{kg})$ than traditional snacks $(0.86 \mathrm{mg} / \mathrm{kg})(\mathrm{p}=0.004)$ (Fig. 3). To the best of our knowledge, the HMF and furfural content in novel snack formulations has not been discussed previously in the scientific literature.

As previously discussed for acrylamide, HMF and furfural formation depends greatly on the presence of precursors in the recipe and the conditions of the thermal process used. The addition of sugar in the caramelized bar shaped Japanese snack could therefore justify the high levels of HMF found in this snack $(91.3 \mathrm{mg} / \mathrm{kg}$ ) (Table 3). Similarly, the high reducing sugar content of roots could promote the higher formation of HMF in vegetable chips (Table 4). In fact, root-based novel formulations also demonstrated a raised acrylamide concentration, suggesting that the presence of sugar could be a key factor for the generation of both of these processing contaminants. The composition of cereals could also contribute to the different levels of HMF and furfural found in the snack formulations. The highest levels were found in 
formulations containing rye and spelt, which concurs with results reported previously. Capuano et al. (2009) reported higher values for HMF in rye bread model systems relative to wheat bread. This might be explained by the higher free amino acids and protein content found in cereal. Spelt is also reported to have higher protein content than common wheat (Kohajdová and Karovicová, 2008), promoting the formation of HMF. This reiterates the importance of conducting risk/benefit analysis when introducing formulations for new food products. In this respect, the incorporation of chia flour in the formulation of biscuits has been reported to be desirable from a nutritional and health perspective, despite the associated increase in the content of process contaminants such as HMF and furfural (Mesias et al., 2016).

Taking a similar approach, exposure to HMF and furfural within the Spanish population through the consumption of the various snacks was estimated. In the case of HMF, traditional snacks were estimated to provide a mean of $0.38 \mu \mathrm{g} / \mathrm{kg}$ bw/day (range: $0.01-5.05 \mu \mathrm{g} / \mathrm{kg}$ bw/day) and novel formulations a mean of 1.02 $\mu \mathrm{g} / \mathrm{kg}$ bw/day (range: $0.02-5.24 \mu \mathrm{g} / \mathrm{kg}$ bw/day) (Table 5). In the case of furfural, contributions were estimated to be $0.05 \mu \mathrm{g} / \mathrm{kg}$ bw/day (range: $0.0 \mathrm{I}-0.2 \mathrm{l} \mu \mathrm{g} / \mathrm{kg}$ bw/day) and $0.14 \mu \mathrm{g} / \mathrm{kg}$ bw/day (range: $0.0 \mathrm{l}-0.57 \mu \mathrm{gkg}$ bw/day) for traditional and novel snacks groups, respectively. Rufián-Henares and de la Cueva (2008) reported a mean exposure to HMF of $10 \mathrm{mg} /$ day within the Spanish population. Using this data it would follow that traditional snacks and novel formulations contribute $0.27 \%$ and $0.71 \%$, respectively, to overall HMF exposure.

It is well known that the formation of products through the Maillard reaction directly depends on the content of amino acids and reducing sugars, $\mathrm{pH}$, moisture, and water activity of the food (Friedman, 1996). Despite parameters concerning the raw matters being unknown, the present study conducted statistical analyses of the relationships between the content of process contaminants and the nutritional composition of snacks, as declared by manufacturer. Analysis of Spearman correlations for non-parametric variables uncovered a significant relationship between HMF and sugar content $(\rho=0.389, p=0.000)$. No significant correlations were observed with regards to furfural. On the other hand, correlations between the measured process contaminants were significant, as follows: acrylamide and HMF $(\rho=0.293, p=0.010)$, acrylamide and furfural $(\rho=0.366, p=0.00 \mathrm{I})$, and HMF and furfural $(\rho=0.465, p=0.000)$.

\section{CONCLUSIONS}

The present study summarizes the presence of acrylamide, HMF and furfural in different categories of traditional and novel snacks. Results highlight that the reformulation of traditional snacks does not meet objectives for mitigating processing contaminants, despite being aimed towards healthier nutritional profiles, reducing fat and salt and increasing fiber content. Levels of acrylamide were higher in certain novel snacks, specifically those made from mixed dough, potato and/or other vegetables. These snacks even exceeded the reference value of $750 \mu \mathrm{g} / \mathrm{kg}$ established for acrylamide in potato products by the recent European regulation for potato-based snacks. Novel formulations for snacks also promoted to an even greater extent the formation of HMF and furfural. In this case, significant differences were found between traditional and novel snacks. Importantly, the present study reveals that the snack industry should not only consider the health-promoting benefits and sensorial characteristic modifications of products. It must also take into account the toxicological aspects of the process contaminants when designing novel products for release into the food market. To this end, it is recommended to include a risk/benefit evaluation of the control of process contaminants when designing novel snack formulas. The present study, therefore, urges food safety authorities to consider including a subgroup of non potato dough-based snacks when developing strategies for the control of acrylamide in foods. This will ensure that "healthy snacking habits" are also included within the global strategy for acrylamide mitigation. 


\section{CONFLICTS OF INTEREST}

The authors declare that they have no conflict of interest.

\section{ACKNOWLEDGMENTS}

This work was funded by projects SI0I3/ABI-3028-AVANSECAL (CAM) and CSIC-2017701025 (Spanish National Research Council). The authors thank Mr. Guillermo Medina, Ms. I. Alvarez, Ms. B. Díaz and Ms. S. Jiménez for their technical assistance.

\section{REFERENCES}

Açar, O.C., Gökmen, V., 2009. Investigation of acrylamide formation on bakery products using a crust-like model. Mol. Nutr. Food Res. 53, I521-1525.

AFAP (Asociación de Fabricante de Aperitivos). (2015). Retrieved January 15, 2018 from: https://www.afapaperitivos.com/el-sector.

Bartelme, M.Z., 2016. Consumers get serious about snacking. Food Technol. 70, 30-45.

Becalski, A., Lau, B.P.Y., Lewis, D., Seaman, S.W., Hayward, S., Sahagian, M., Ramesh, M., Leclerc, Y., 2004. Acrylamide in french fries: Influence of free amino acids and sugars. J. Agric. Food Chem. 52, 380I-3806.

Brennan, M.A., Derbyshire, E., Tiwari, B.K., Brennan, C.S., 2013. Ready-to-eat snack products: the role of extrusion technology in developing consumer acceptable and nutritious snacks. Int. J. Food Sci. Technol. 48, 893-902.

Capuano, E., Ferrigno, A., Acampa, I., Serpen, A., Acar, O.C., Gokmen, V., Fogliano, V., 2009. Effect of flour type on Maillard reaction and acrylamide formation during toasting of bread crisp model systems and mitigation strategies. Food Res. Int. 42, I295-1302.

Cheng, K.W., Shi, J.J., Ou, S.Y., Wang, M., Jiang, Y., 2010. Effects of fruit extracts on the formation of acrylamide in model reactions and fried potato crisps. Journal of Agriculture and Food Chemistry 58, 309$3 \mid 2$.

Cheng, W.C., Sun, D.C., Chou, S.S., Yeh, A.I., 2012. Acrylamide content distribution and possible alternative ingredients for snack foods. J. Food Prot. 75, 2158-2162.

Daniali, G., Jinap, S., Zaidul, S.I.M., Hanifah, N.L., 20I0. Determination of acrylamide in banana based snacks by gas chromatography-mass spectrometry. Int. Food Res. J. 17, 433-439.

Dehghannya, J., Abedpour, L., 2018. Influence of a three stage hybrid ultrasound-osmotic-frying process on production of low-fat fried potato strips. J. Sci. Food Agric. 98, |485-|49|.

Dueik, V., Robert, P., Bouchon, P., 2010. Vacuum frying reduces oil uptake and improves the quality parameters of carrot crisps. Food Chem. II9, II43-1 I49.

EFSA (European Food Safety Agency), 2005. Opinion of the Scientific Panel on Food Additives, Flavourings, Processing Aids and Materials in Contact With Food (AFC) Related to Flavouring Group Evaluation 13 (FGE.I3); Furfuryl and Furan Derivatives With and Without Additional Sidechain Substituents and Heteroatoms From Chemical Group 14. Retrieved January 2, 2018 from: http://www.efsa.europa.eu/en/efsajournal/pub/2I5. 
EFSA (European Food Safety Agency), 2015. Scientific opinion on acrylamide in food. Efsa J. 13, 4I04. $\begin{array}{llll}\text { Retrieved January } & 2, & 2018 & \text { from. }\end{array}$ http://www.efsa.europa.eu/sites/default/files/scientific_output/files/main_documents/4I04.pdf.

Elmore, J.S., Koutsidis, G., Dodson, A.T., Mottram, D.S., Wedzicha, B.L., 2005. Measurement of acrylamide and its precursors in potato, wheat, and rye model systems. J. Agric. Food Chem. 53, 1286-1293.

European Commission, 2017. Comission Regulation (EU) 2017/2158 of 20 november 2017 establishing mitigation measures and benchmark levels for the reduction of the presence of acrylamide in food. Off. J. Eur. Union L304, 24-44.

FAO/WHO (Joint FAO/WHO Expert Committee on Food Additives), 2010. Summary Report of the Seventy-second Meeting of JECFA. Retrieved January 2, 2018 from: FAO/WHO (Joint FAO/WHO Expert Committee on Food Additives), Rome, Italy. http://www.who.int/foodsafety/chem/summary72_rev.pdf.

Farkas, B.E., Singh, R.P., Rumsey, T.R., 1996. Modeling heat and mass transfer in immersion frying. I, model development. J. Food Eng. 29, 21I-226.

Fast, R., 200I. Breakfast cereals. In: Owens, G. (Ed.), Cereals Processing Technology. Woodhead Publishing, Cambridge, UK, pp. I58-172.

FDA (US Food and Drug Administration), 2006. Survey Data on Acrylamide in Food: Individual Food $\begin{array}{lllll}\text { Products. } & \text { Retrieved } & \text { January } & 2018 & \text { from. }\end{array}$ https://www.fda.gov/Food/FoodbornelllnessContaminants/ChemicalContaminants/ucm053549.htm.

Friedman, M., 1996. Food Browning and its prevention: an overview. J. Agric. Food Chem. 44, 63 I-653.

Gökmen, V., Palazoğlu, T.K., Șenyuva, H.Z., 2006. Relation between the acrylamide formation and timetemperature history of surface and core regions of French fries. J. Food Eng. 77, 972-976.

Granby, K., Nielsen, N.J., Hedegaard, R.V., Christensen, T., Kann, M., Skibsted, L.H., 2008. Acrylamideasparagine relationship in baked/toasted wheat and rye breads. Food Addit. Contam. A Chem. Anal. Control Exp. Risk Assess. Foreword 25, 921-929.

Han, J.J., Janz, J.A.M., Gerlat, M., 2010. Development of gluten-free cracker snacks using pulse flours and fractions. Food Res. Int. 43, 627-633.

Høie, A.H., Svendsen, C., Brunborg, G., Glatt, H., Alexander, J., Meinl, W., Husøy, T., 20I5. Genotoxicity of three food processing contaminants in transgenic mice expressing human sulfotransferases IAI and IA2 as assessed by the in vivo alkaline single cell gel electrophoresis assay. Environ. Mol. Mutagen. 56, 709-7|4.

Jaenke, R., Barzi, F., McMahon, E., Webster, J., Brimblecombe, J., 2017. Consumer acceptance of reformulated food products: a systematic review and meta-analysis of salt-reduced foods. Crit. Rev. Food Sci. Nutr. 57, 3357-3372.

Kohajdová, Z., Karovicová, J., 2008. Nutritional value and baking applications of spelt wheat. Acta Sci. Pol. Technol. Aliment. 7, 5-I4. 
Komthong, P., Suriyaphan, O., Charoenpanich, J., 2012. Determination of acrylamide in Thai-conventional snacks from Nong Mon market, Chonburi using GC-MS technique. Food Addit. Contam.: B Surveill. 5, 2028.

Krokida, M.K., Oreopoulou, V., Maroulis, Z.B., Marinos-Kouris, D., 200I. Colour changes during deep fat frying. J. Food Eng. 48, 219-225.

MAPAMA (Ministerio de Agricultura, Alimentación y Medio Ambiente), 2017. Informe Del Consumo De

Alimentos En España 2017. Retrieved December II, 2018 from: https://www.mapa.gob.es/es/alimentacion/temas/consumo-y-comercializacion-ydistribucionalimentaria/informeanualdeconsumoalimentario2017_tcm30-456186.pdf.

Masatcioglu, M.T., Gokmen, V., Ng, P.K.W., Koksel, H., 20l4. Effects of formulation, extrusion cooking conditions, and $\mathrm{CO} 2$ injection on the formation of acrylamide in corn extrudates. J. Sci. Food Agric. 94, 2562-2568.

Mesias, M., Morales, F.J., 2015. Acrylamide in commercial potato crisps from Spanish market: trends from 2004 to 2014 and assessment of the dietary exposure. Food Chem. Toxicol. 81, 104-110.

Mesias, M., Holgado, F., Marquez-Ruiz, G., Morales, F.J., 2015. Effect of sodium replacement in cookies on the formation of process contaminants and lipid oxidation. LWT-Food Sci. Technol. 62, 633-639.

Mesias, M., Holgado, F., Márquez-Ruiz, G., Morales, F.J., 2016. Risk/benefit considerations of a new formulation of wheat-based biscuit supplemented with different amounts of chia flour. LWT-Food Sci. Technol. 73, 528-535.

Mesias, M., Delgado-Andrade, C., Morales, F.J., 2018. Alternative food matrices for snack formulations in terms of acrylamide formation and mitigation. J. Sci. Food Agric. I-4.

Mojska, H., Gielecinska, I., Szponar, L., Ołtarzewski, M., 20I0. Estimation of the dietary acrylamide exposure of the Polish population. Food Chem. Toxicol. 48, 2090-2096.

Morales, F.J., 2008. Hydroxymethylfurfural (HMF) and related compounds. In: Stadler, R.H., Lineback, D.R. (Eds.), Process-Induced Food Toxicants: Occurrence, Formation, Mitigation, and Health Risks. John Wiley \& Sons, Inc., New Jersey, Pp. I35-174.

Nath, A., Chattopadhyay, P.K., 2007. Optimization of oven toasting for improving crispness and other quality attributes of ready to eat potato-soy snack using response surface methodology. J. Food Eng. 80, I282-1292.

Niva, M., 2007. All foods affect health: understandings of functional foods and healthy eating among healthoriented Finns. Appetite 48, 384-393.

Pastoriza de la Cueva, S., Álvarez, J., Végvári, Á., Montilla-Gómez, J., Cruz-López, O., Delgado-Andrade, C., Rufián-Henares, J.A., 2017. Relationship between HMF intake and SMF formation in vivo: an animal and human study. Mol. Nutr. Food Res. 6I, 1600773.

Pugajeva, I., Zumbure, L., Melngaile, A., Bartkevics, V., 20I4. Determination of acrylamide levels in selected foods in Latvia and assessment of the population intake. Foodbalt 20I4, Conference Proceedings. PP. II I116. 
Riaz, M.N., 2016. Snack foods: processing. In: Wrigley, C., Corke, H., Seetharaman, K., Faubion, J. (Eds.), Encyclopedia of Food Grains. Elsevier, Amsterdam, pp. 4I4-422.

Rufían-Henares, J.A., de la Cueva, S.P., 2008. Assessment of hydroxymethylfurfural intake in the Spanish diet. Food Addit. Contam. Part A Chem. Anal. Control Expo. Risk Assess. 25, 1306-1312.

Rufián-Henares, J.A., Delgado-Andrade, C., Morales, F.J., 2009. Assessing the Maillard reaction development during the toasting process of common flours employed by the cereal products industry. Food Chem. II4, 93-99.

Shamla, L., Nisha, P., 20I4. Acrylamide in deep-fried snacks of India. Food Addit. Contam. B 7, 220-225.

Sirot, V., Hommet, F., Tard, A., Leblanc, J.C., 2012. Dietary acrylamide exposure of the French population: results of the second French Total Diet Study. Food Chem. Toxicol. 50, 889-894.

Stadler, R.H., Studer, A., 2017. Acrylamide formation mechanisms. In: Gökmen, V. (Ed.), Acrylamide in Food. Analysis, Content and Potential Health Effects. Academic Press, London, UK, Pp. I-I7.

Takatsuki, S., Nemoto, S., Sasaki, K., Maitani, T., 2003. Determination of acrylamide in processed foods by LC/MS using column switching. Shokuhin Eiseigaku Zasshi 44, 89-95.

Tardiff, R.G., Gargas, M.L., Kirman, C.R., Carson, M.L., Sweeney, L.M., 20I0. Estimation of safe dietary intake levels of acrylamide for humans. Food Chem. Toxicol. 48, 658-667.

Williams, J.S.E., 2005. Influence of variety and processing conditions on acrylamide levels in fried potato crisps. Food Chem. 90, 875-881.

Zamora, R., Hidalgo, F.J., 20I I. The Maillard reaction and lipid oxidation. Lipid Technol. 23, 59-62.

Zubeldia Lauzurica, L., Gomar Fayos, J., 2007. Acrilamida en patatas fritas y productos de aperitivo elaborados en la Comunidad Valenciana. Gac. Sanit. 21, 334-337. 
FIGURES AND TABLES

Table I. Nutritional composition of traditional snacks per $100 \mathrm{~g}$ of sample. Information provided by the manufacturer

\begin{tabular}{|c|c|c|c|c|c|c|c|c|}
\hline Sample & $\begin{array}{r}\text { Energy } \\
\text { (Kcal) }\end{array}$ & $\begin{array}{c}\text { Total fat } \\
\text { (g) }\end{array}$ & $\begin{array}{c}\text { Saturated fat } \\
\text { (g) }\end{array}$ & $\begin{array}{c}\text { Carbohydrates } \\
\text { (g) }\end{array}$ & $\begin{array}{r}\text { Sugars } \\
\text { (g) }\end{array}$ & $\begin{array}{r}\text { Fiber } \\
\text { (g) }\end{array}$ & $\begin{array}{l}\text { Protein } \\
\text { (g) }\end{array}$ & $\begin{array}{r}\text { Salt } \\
\text { (g) }\end{array}$ \\
\hline \multicolumn{9}{|l|}{ Cereal based } \\
\hline Cheese flavored corn snack & 556 & 35.5 & 11.3 & 53.5 & 2.3 & na & 5.5 & 1.5 \\
\hline Corn strip & 567 & 33 & 17 & 57 & 2.2 & 4.5 & 5 & 1.5 \\
\hline Corn cake & 407 & 2.6 & 0.3 & 85.6 & 1 & 2 & 9.2 & 2.2 \\
\hline Corn chip & 512 & 26.7 & 10.2 & 60.6 & 2.1 & 4.2 & 5.5 & 1.2 \\
\hline Spicy rolled corn snack & 533 & 28 & 8.1 & 62 & 9 & 5.4 & 5.6 & 2.8 \\
\hline Puffcorn bars & 467 & 17.4 & 2.2 & 71.1 & I & na & 6.6 & 2 \\
\hline Puffcorn & 474 & 18.6 & 2.4 & 71 & 1.5 & na & 5.6 & 1.8 \\
\hline Corn snack cones & 512 & 28 & 3.8 & 57.3 & 5.1 & 3.1 & 6.3 & 2.4 \\
\hline Polynesian corn flavored chip & 497 & 25 & 3 & 58 & 3.3 & 6.9 & 6.1 & 1.9 \\
\hline Corn and onion chip & 524 & 26.5 & 8.7 & 61.9 & 3.7 & 6 & 6.5 & 0.8 \\
\hline Ring shaped corn snack & 530 & 24 & $\mathrm{II} . \mathrm{I}$ & 71.1 & 0.5 & na & 5.7 & 3.7 \\
\hline Corn snack with barbecue flavor & 543 & 32.2 & 14.7 & 54.9 & 4.8 & 4.6 & 6.1 & 1.5 \\
\hline Corn based snack & 533 & 28 & 3.1 & 63 & 0.5 & 3.1 & 5 & 1.5 \\
\hline Cheese puff & 503 & 27 & 3.8 & 59.2 & 6.3 & 1.2 & 5.1 & 2.1 \\
\hline Cheese and ketchup flavor snack & 518 & 29.3 & 4.2 & 56.2 & 4.8 & 2.7 & 6 & 1.7 \\
\hline Sunflower seed stick & 526 & 32 & 4.5 & 48 & 4 & na & 10 & 2.03 \\
\hline Cracker with puffed rice & 428 & 9.5 & 1.4 & 74 & 2.2 & 2.5 & I & 1.3 \\
\hline Pretzel stick & 393 & 5.9 & 0.8 & 71 & 3.4 & 4 & 12 & 4.5 \\
\hline Salty cracker & 473 & 18 & 1.6 & 70 & 6 & na & 6.7 & 2 \\
\hline Salty cookie & 508 & 26 & 9.9 & 62 & 9 & na & 6 & 2 \\
\hline Spicy and salty cookie & 414 & 10 & 3.8 & 69 & 3.8 & 4 & 10 & 3 \\
\hline Salty cookie with sesame & 414 & 10 & 3.8 & 69 & 3.8 & 4 & 10 & 3 \\
\hline Brezel cracker & 414 & 10 & 3.8 & 69 & 3.8 & 4 & 10 & 3 \\
\hline Brezel mini stick & 414 & 10 & 3.8 & 69 & 3.8 & 4 & 10 & 3 \\
\hline
\end{tabular}




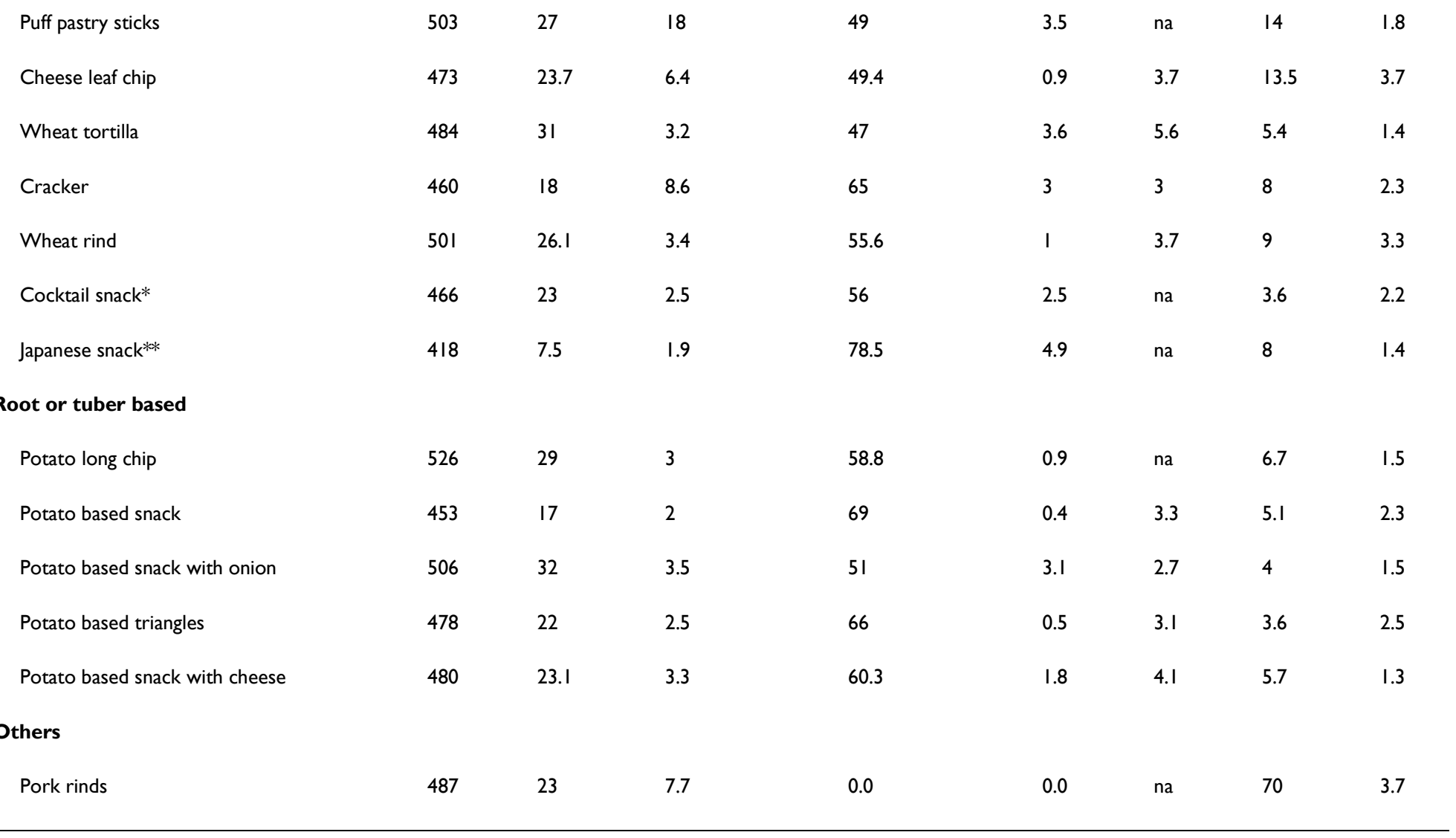

na: not available. *Cocktail snack: onion flavored ring, grill snack, bacon strip snack, potato based ring, ketchup flavored snack. ** Japanese snack: Loop shaped, triangle shaped, flower shaped, bar shaped, caramelized bar shaped, ball shaped. 
Table 2. Nutritional composition of novel formulations of snacks per $100 \mathrm{~g}$ of sample. Information provided by the manufacturer.

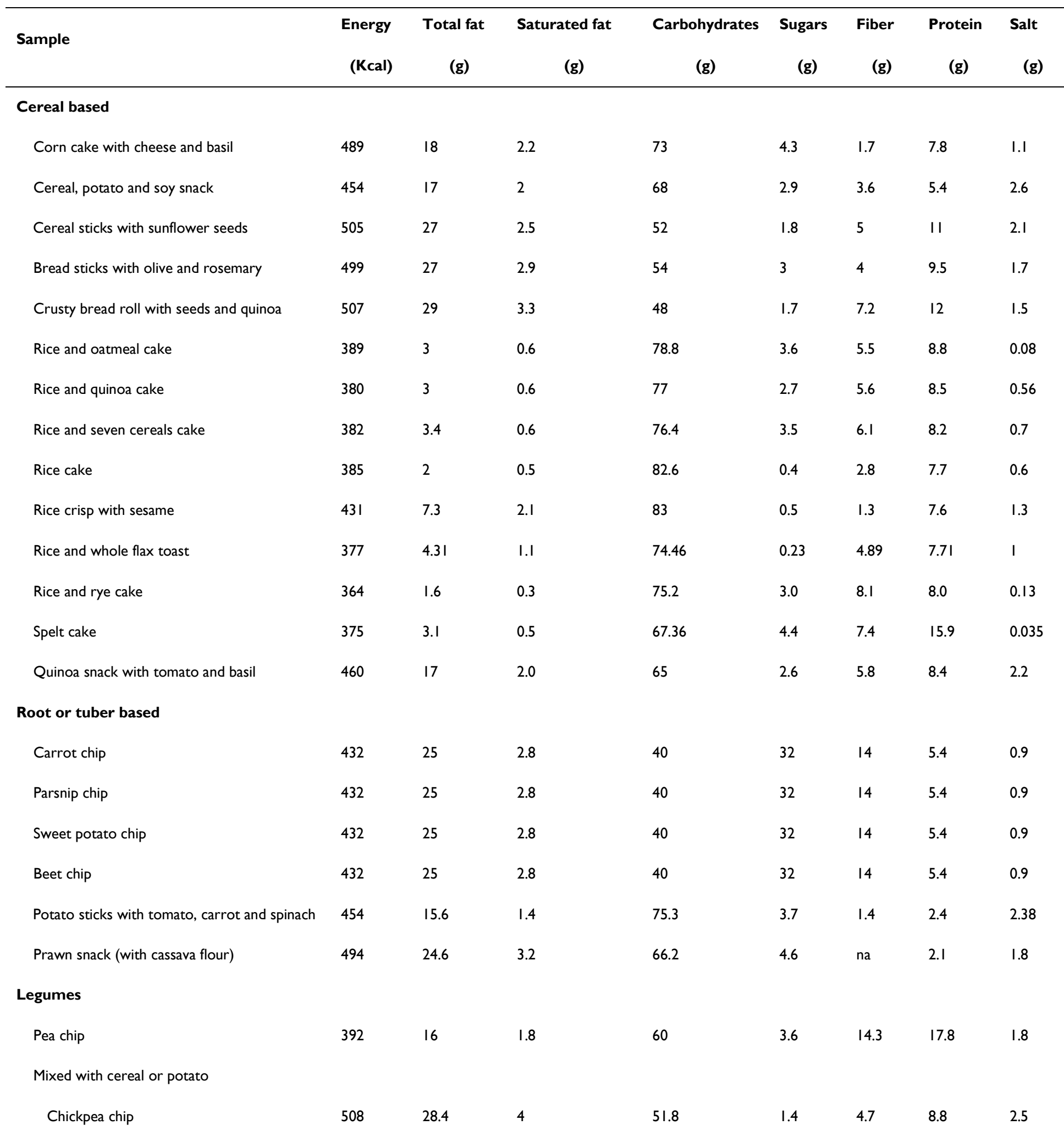


Lentil chip

Pea snack with cheese and dill

Chickpea, corn and rice ring

Hummus snack with basil and parsley

Lentil snack with cheese and spices

\section{Others}

Salty banana chip

Seaweed chip
$474 \quad 21.5$

463

463

459

47I

497

403
2.5

2.2

2.2

2

2.3

11.3

I
56.2

60

73.5

61

56

63

78.6
I.I

3.9

3.3

2.9

5.2

2.7

5.2

5.2
3.9

0.92

2.1

1.9

na: not available. 
Table 3. Acrylamide, HMF and Furfural content in traditional snacks.

\begin{tabular}{|c|c|c|c|}
\hline Sample & Acrylamide ( $\mu \mathrm{g} / \mathrm{kg})$ & HMF (mg/kg) & Furfural (mg/kg) \\
\hline \multicolumn{4}{|l|}{ Cereal based } \\
\hline Cheese flavored corn snack & $73 \pm 0.3$ & $0.6 \pm 0.0$ & nd \\
\hline Corn strip & $279 \pm 4.2$ & $4.6 \pm 0.3$ & $1.0 \pm 0.1$ \\
\hline Corn cake & $105 \pm 9.6$ & $11.0 \pm 1.0$ & $3.8 \pm 0.2$ \\
\hline Corn chip & $646 \pm 11.8$ & $2.0 \pm 0.0$ & nd \\
\hline Spicy rolled corn snack & $74 \pm 2.1$ & $2.5 \pm 0.0$ & $0.5 \pm 0.0$ \\
\hline Puffcorn bars & $146 \pm 4.7$ & $2.2 \pm 0.3$ & $0.7 \pm 0.0$ \\
\hline Puffcorn & $108 \pm 2.7$ & $1.9 \pm 0.1$ & $1.3 \pm 0.1$ \\
\hline Corn snack cones & $270 \pm 7.8$ & $0.7 \pm 0.0$ & $0.6 \pm 0.0$ \\
\hline Polynesian corn flavored chip & $114 \pm 0.9$ & $3.7 \pm 0.2$ & $\mathrm{I} . \mathrm{I} \pm 0.0$ \\
\hline Corn and onion chip & $536 \pm 8.6$ & $2.9 \pm 0.3$ & $0.7 \pm 0.1$ \\
\hline Ring shaped corn snack & $560 \pm 2.9$ & $0.8 \pm 0.1$ & nd \\
\hline Corn snack with barbecue flavor & $76 \pm 0.9$ & $2.4 \pm 0.0$ & nd \\
\hline Corn based snack & $120 \pm 0.5$ & $0.8 \pm 0.1$ & $0.7 \pm 0.1$ \\
\hline Cheese puff & $48 \pm 0.2$ & $2.5 \pm 0.2$ & $0.7 \pm 0.1$ \\
\hline Cheese and ketchup flavor snack & $660 \pm 80.6$ & $4.2 \pm 0.0$ & $2.9 \pm 0.1$ \\
\hline Sunflower seed stick & $96 \pm 1.9$ & $6.4 \pm 0.7$ & $0.9 \pm 0.0$ \\
\hline Cracker with puffed rice & $69 \pm 3.8$ & $1.0 \pm 0.3$ & $0.6 \pm 0.0$ \\
\hline Pretzel stick & $144 \pm 8.1$ & $4.1 \pm 3.3$ & $1.7 \pm 0.0$ \\
\hline Salty cracker & $68 \pm 1.2$ & $3.4 \pm 0.4$ & nd \\
\hline Salty cookie & $272 \pm 2.4$ & $4.5 \pm 0.1$ & nd \\
\hline Spicy and salty cookie & $267 \pm 5.8$ & $3.0 \pm 0.1$ & nd \\
\hline Salty cookie with sesame & $233 \pm 4.9$ & $2.6 \pm 0.1$ & nd \\
\hline Brezel cracker & $114 \pm 0.1$ & $1.8 \pm 0.0$ & $1.5 \pm 0.0$ \\
\hline Brezel mini stick & $111 \pm 1.9$ & $2.2 \pm 0.1$ & $1.5 \pm 0.0$ \\
\hline Puff pastry sticks & $181 \pm 6.1$ & $9.9 \pm 0.1$ & $0.2 \pm 0.0$ \\
\hline Cheese leaf chip & $44 \pm 2.2$ & $1.1 \pm 0.0$ & $2.7 \pm 0.2$ \\
\hline Wheat tortilla & $102 \pm 2.7$ & $1.2 \pm 0.1$ & $2.0 \pm 0.1$ \\
\hline
\end{tabular}


Cracker

Wheat rind

Onion flavoring rings

Grill snack

Bacon strip snack

Potato based ring

Ketchup flavored snack

Loop shaped Japanese snack

Triangle shaped Japanese snack

Flower shaped Japanese snack

Bar shaped Japanese snack

Caramelized bar shaped Japanese snack

Ball shaped Japanese snack

\section{Root or tuber based}

Potato long chip

Potato based snack

Potato based snack with onion

Potato-based triangles

Potato based snack with cheese

\section{Others}

$262 \pm 2.7$

$145 \pm 7.1$

$335 \pm 7.3$

$491 \pm 3.1$

$86 \pm 0.4$

$272 \pm 29.5$

$671 \pm 0.7$

$78 \pm 1.9$

$70 \pm 0.8$

$72 \pm 1.6$

$75 \pm 0.1$

$63 \pm 0.3$

$75 \pm 8.8$

$76 \pm 2.6$

$180 \pm 3.2$

$74 \pm 3.5$

$123 \pm 1.0$

$246 \pm 5.1$

$53 \pm 0.1$
$1.9 \pm 0.1$

$12.7 \pm 0.6$

$4.0 \pm 0.1$

$1.7 \pm 0.0$

$8.8 \pm 0.3$

$1.3 \pm 0.1$

$2.7 \pm 0.2$

$69.4 \pm 6.6$

$23.7 \pm 0.2$

$15.2 \pm 0.0$

$0.7 \pm 0.1$

$91.3 \pm 1.5$

$2.1 \pm 0.1$

$0.4 \pm 0.0$

$0.9 \pm 0.0$

$0.4 \pm 0.0$

$0.6 \pm 0.0$

$0.4 \pm 0.0$

nd nd

nd

$0.6 \pm 0.1$

$2.7 \pm 0.1$

$I . I \pm 0.1$

$2.1 \pm 0.0$

$3.1 \pm 0.2$

nd

nd

nd

nd

nd

$0.7 \pm 0.1$

$0.6 \pm 0.0$

$0.6 \pm 0.1$

$0.3 \pm 0.0$

nd

nd

$0.4 \pm 0.0$

nd: not detected. 
Table 4. Acrylamide, HMF and Furfural content in novel formulations of snacks.

\begin{tabular}{|c|c|c|c|}
\hline Sample & Acrylamide $(\mu \mathrm{g} / \mathrm{kg})$ & HMF (mg/kg) & Furfural (mg/kg) \\
\hline \multicolumn{4}{|l|}{ Cereal based } \\
\hline Corn cake with cheese and basil & $143 \pm 1.6$ & $10.4 \pm 0.1$ & $3.0 \pm 0.1$ \\
\hline Cereal, potato and soy snack & $1393 \pm 65.2$ & $9.4 \pm 0.2$ & $2.5 \pm 0.1$ \\
\hline Cereal sticks with sunflower seeds & $106 \pm 5.5$ & $5.8 \pm 0.0$ & $1.4 \pm 0.0$ \\
\hline Bread sticks with olive and rosemary & $112 \pm 4.2$ & $10.5 \pm 0.4$ & $2.2 \pm 0.1$ \\
\hline Crusty bread roll with seeds and quinoa & $78 \pm 2.4$ & $15.6 \pm 0.1$ & $1.5 \pm 0.0$ \\
\hline Rice and oatmeal cake & $253 \pm 9.1$ & $25.4 \pm 2.7$ & $4.1 \pm 0.3$ \\
\hline Rice and quinoa cake & $191 \pm 1.6$ & $30.3 \pm 2.5$ & $4.5 \pm 0.2$ \\
\hline Rice and seven cereals cake & $178 \pm 20.6$ & $10.5 \pm 1.2$ & $2.5 \pm 0.2$ \\
\hline Rice cake & $147 \pm 10.0$ & $14.6 \pm 0.1$ & $2.9 \pm 0.1$ \\
\hline Rice crisp with sesame & $69 \pm 1.1$ & $1.3 \pm 0.0$ & $0.4 \pm 0.0$ \\
\hline Rice and whole flax toast & $52 \pm 0.4$ & $0.4 \pm 0.0$ & $0.4 \pm 0.0$ \\
\hline Rice and rye cake & $341 \pm 28.6$ & $73.2 \pm 6.1$ & $10.3 \pm 0.8$ \\
\hline Spelt cake & $594 \pm 11.2$ & $63.5 \pm 2.1$ & $9.8 \pm 0.6$ \\
\hline Quinoa snack with tomato and basil & $32 \pm 0.8$ & $1.8 \pm 0.2$ & $1.0 \pm 0.1$ \\
\hline \multicolumn{4}{|l|}{ Root or tuber based } \\
\hline Carrot chip & $958 \pm 73.4$ & $92.1 \pm 3.4$ & $9.4 \pm 0.3$ \\
\hline Parsnip chip & $235 \pm 13.7$ & $94.7 \pm 6.3$ & $2.3 \pm 0.2$ \\
\hline Sweet potato chip & $265 \pm 4.6$ & $53.2 \pm 0.5$ & $6.4 \pm 0.2$ \\
\hline Beet chip & $908 \pm 32.0$ & $27.5 \pm 0.7$ & $3.7 \pm 0.0$ \\
\hline Potato sticks with tomato & $684 \pm 1.1$ & $2.2 \pm 0.1$ & $\mathrm{I} . \mathrm{I} \pm 0.0$ \\
\hline Potato sticks with carrot & $1252 \pm 15.6$ & $13.3 \pm 0.9$ & $2.7 \pm 0.2$ \\
\hline Potato sticks with spinach & $354 \pm 6.0$ & $1.3 \pm 0.1$ & nd \\
\hline Prawn snack (with cassava flour) & $36 \pm 0.4$ & $1.4 \pm 0.1$ & nd \\
\hline \multicolumn{4}{|l|}{ Legumes } \\
\hline Pea chip & nd & $1.5 \pm 0.0$ & $0.8 \pm 0.0$ \\
\hline \multicolumn{4}{|l|}{ Mixed with cereal or potato } \\
\hline Chickpea chip & $40 \mathrm{I} \pm 7.5$ & $1.2 \pm 0.1$ & $0.9 \pm 0.1$ \\
\hline
\end{tabular}


Lentil chip

Pea snack with cheese and dill

Chickpea, corn and rice ring

Hummus snack with basil and parsley

Lentil snack with cheese and spices

\section{Others}

Salty banana chip

Seaweed chip
$317 \pm 0.3$

$64 \pm 0.7$

$102 \pm 3.7$

$55 \pm 0.4$

$45 \pm 0.0$

$240 \pm 20.3$

$43 \pm 1.0$
$1.0 \pm 0.0$

$0.6 \pm 0.0$

$\mathrm{I} . \mathrm{I} \pm 0 . \mathrm{I}$

$3.7 \pm 0.1$

$1.2 \pm 0.0$

$3.9 \pm 0.4$

$1.4 \pm 0.0$ nd

nd

$I . I \pm 0.1$

$0.9 \pm 0.1$

nd

$1.7 \pm 0.1$

nd

nd: not detected. 
Table 5. Exposure to acrylamide (ACR), hydroxymethylfurfural (HMF) and furfural through the consumption of snacks.

\begin{tabular}{|c|c|c|c|c|c|c|}
\hline & Mean \pm SD & Minimum & Maximum & $\mathbf{P 2 5}$ & P75 & P95 \\
\hline \multicolumn{7}{|l|}{ ACR (ng/kg bw/day) } \\
\hline Traditional & $10.77 \pm 17.22 \mathrm{~A}$ & 2.43 & 37.10 & 4.13 & 14.8 & 36.22 \\
\hline Novel formulations & $17.22 \pm 20.14 \mathrm{~A}$ & 0.55 & 77.01 & 3.54 & 19.57 & 72.33 \\
\hline \multicolumn{7}{|l|}{ HMF ( $\mu \mathrm{g} / \mathrm{kg}$ bw/day) } \\
\hline Traditional & $0.38 \pm 0.92 \mathrm{~A}$ & 0.01 & 5.05 & 0.05 & 0.23 & 2.95 \\
\hline Novel formulations & $1.02 \pm 1.51 \mathrm{~B}$ & 0.02 & 5.24 & 0.07 & 1.40 & 5.15 \\
\hline \multicolumn{7}{|l|}{ Furfural ( $\mu \mathrm{g} / \mathrm{kg}$ bw/day) } \\
\hline Traditional & $0.05 \pm 0.52 \mathrm{~A}$ & 0.01 & 0.21 & 0.01 & 0.06 & 0.17 \\
\hline Novel formulations & $0.14 \pm 0.16 \mathrm{~B}$ & 0.01 & 0.01 & 0.02 & 0.16 & 0.55 \\
\hline
\end{tabular}

Different letters indicate statistically significant differences $(p<0.05)$ between the groups of traditional snacks $(n=46)$ and novel formulations of snacks $(n=3 I)$. 
Figure I. Box-and-whisker plot of acrylamide content in traditional and novel formulations of snacks. Differences were not found significant ( $\mathrm{P}>0.05$ ). Mean values: $194 \mu \mathrm{g} / \mathrm{kg}$ (traditional), $263 \mu \mathrm{g} / \mathrm{kg}$ (novel).

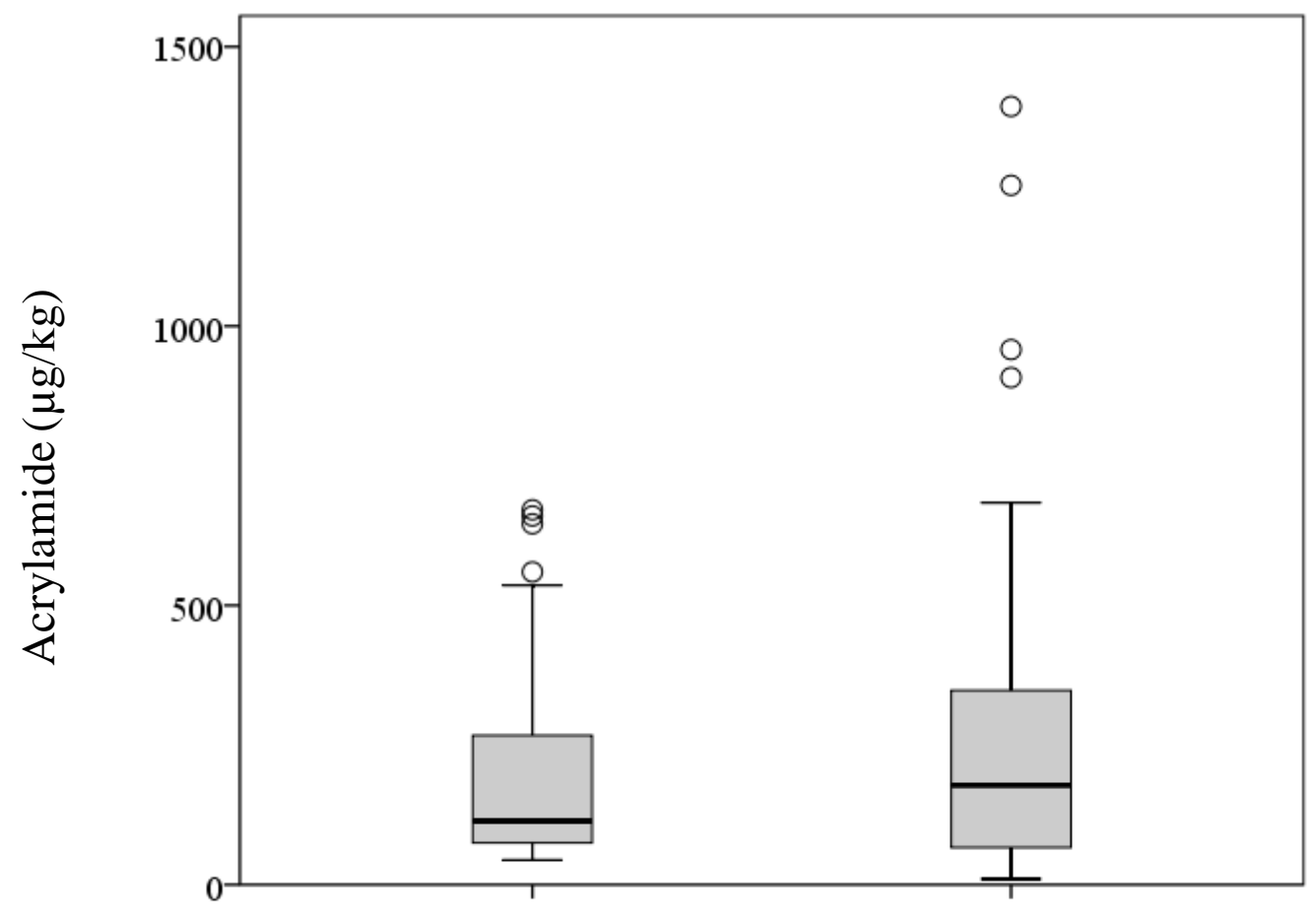

Traditional Novel 
Figure 2. Box-and-whisker plot of hydroxymethylfurfural content (HMF) in traditional and novel formulations of snacks. * Differences were found significant $(p<0.05)$. Mean values: $7.00 \mathrm{mg} / \mathrm{kg}$ (traditional), $18.52 \mathrm{mg} / \mathrm{kg}$ (novel).

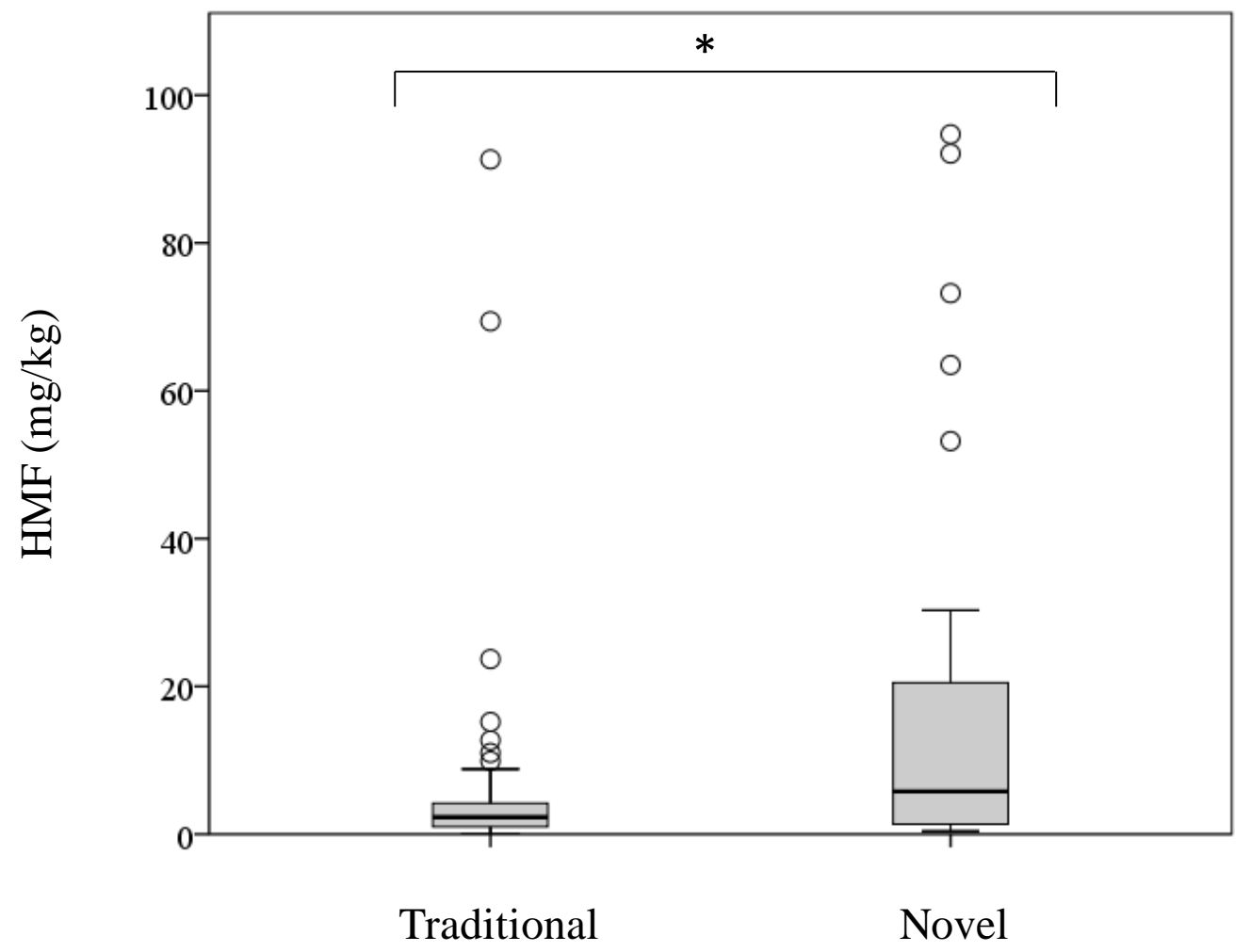


Figure 3. Box-and-whisker plot of furfural content in traditional and novel formulations of snacks. * Differences were found significant $(\mathrm{p}<0.05)$. Mean values: $0.86 \mathrm{mg} / \mathrm{kg}$ (traditional), $2.53 \mathrm{mg} / \mathrm{kg}$ (novel).

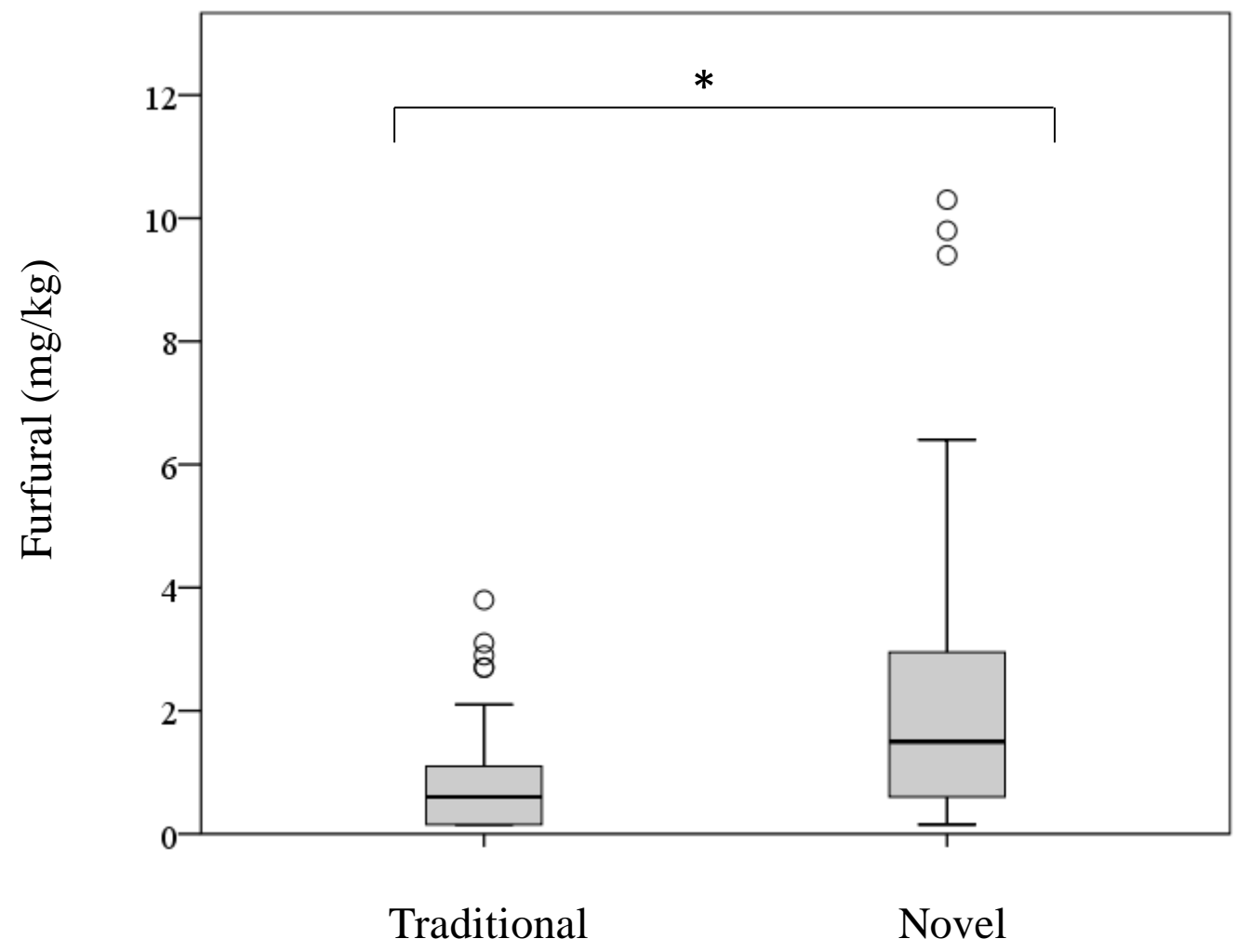




\section{Supplementary Material}

Annex I. Major ingredients in the traditional snacks.

\begin{tabular}{|c|c|}
\hline Sample & Major ingredients \\
\hline \multicolumn{2}{|l|}{ Cereal based } \\
\hline Cheese flavoured corn snack & Corn flour, cheese \\
\hline Corn strip & Corn flour \\
\hline Corn cake & Corn flour \\
\hline Corn chip & Corn flour \\
\hline Spicy rolled corn snack & Corn flour \\
\hline Puffcorn bars & Corn flour \\
\hline Puffcorn & Corn flour \\
\hline Corn snack cones & Corn flour \\
\hline Cheese puff & Corn flour, cheese \\
\hline Polynesian corn flavoured chip & Corn flour \\
\hline Corn and onion chip & Corn flour, onion \\
\hline Ring shaped corn snack & Corn flour \\
\hline Corn snack with barbecue flavour & Corn flour, barbecue sauce \\
\hline Corn based snack & Corn and potato flour \\
\hline Cheese and ketchup flavour snack & Corn, wheat and potato flour, cheese, ketchup \\
\hline Sunflower seed stick & Wheat flour, sunflower seeds \\
\hline Cracker with puffed rice & Wheat flour, rice \\
\hline Pretzel stick & Wheat flour \\
\hline Salty cracker & Wheat flour \\
\hline Salty cookie & Wheat flour \\
\hline Spicy and salty cookie & Wheat flour \\
\hline Salty cookie with sesame & Wheat flour, sesame seeds \\
\hline Brezel cracker & Wheat flour \\
\hline Brezel mini stick & Wheat flour \\
\hline Puff pastry sticks & Wheat flour, butter, cheese, skim milk powder \\
\hline Cheese leaf chip & Wheat flour, cheese \\
\hline
\end{tabular}


Wheat tortilla

Cracker

Wheat rind

Cocktail snack*

Japanese snack**

Root or tuber based

Potato long chip

Potato based snack

Potato based snack onion

Potato-based triangles

Potato based snack with cheese

\section{Others}

Pork rinds
Wheat flour

Wheat flour

Wheat flour

Wheat, rye, corn and potato flour

Wheat, cassava and corn flour, soybean sauce, seaweed

Potato and wheat flour

Potato

Potato flour, sour cream, onion

Potato and corn flour

Potato, wheat and corn flour, cheese

Pork rind

*Cocktail snack: onion flavoured ring, grill snack, bacon strip snack, potato based ring, ketchup flavoured snack. **Japanese snack: Loop shaped, triangle shaped, flower shaped, bar shaped, caramelized bar shaped, ball shaped. 


\section{Supplementary Material}

Annex 2. Major and singular ingredients of novel snacks.

\begin{tabular}{|c|c|}
\hline Sample & Major and singular ingredients \\
\hline \multicolumn{2}{|l|}{ Cereal based } \\
\hline Corn cake with cheese and basil & Corn flour, cheese, basil \\
\hline Cereal, potato and soy snack & $\begin{array}{l}\text { Corn and potato flour, soybean, cheese, tomato, } \\
\text { aromatic plants }\end{array}$ \\
\hline Cereal sticks with sunflower seeds & Wheat \\
\hline Bread sticks with olive and rosemary & Wheat flour, black olives, tomato, rosemary \\
\hline Crusty bread roll with seeds and quinoa & Wheat and quinoa flour, sesame seeds \\
\hline Rice and oatmeal cake & Rice and oatmeal flour \\
\hline Rice and quinoa cake & Rice and quinoa flour \\
\hline \multicolumn{2}{|l|}{ Rice and seven cereals cake } \\
\hline Rice cake & Rice flour \\
\hline Rice crisp with sesame & Rice flour, sesame seeds \\
\hline Rice and whole flax toast & Rice and flax flour \\
\hline Rice and rye cake & Whole rice and rye flour \\
\hline Spelt cake & Spelt flour \\
\hline Quinoa snack with tomato and basil & Whole quinoa and rice flour, potato, tomato, basil \\
\hline \multicolumn{2}{|l|}{ Root or tuber based } \\
\hline Carrot chip & Carrot \\
\hline Parsnip chip & Parsnip \\
\hline Sweet potato chip & Sweet potato \\
\hline Beet chip & Beet \\
\hline Potato sticks with tomato, carrot and spinach & Potato flour, tomato, carrot, spinach \\
\hline Prawn snack (with cassava flour) & Cassava flour, prawn, egg, sugar \\
\hline \multicolumn{2}{|l|}{ Legumes } \\
\hline Pea chip & Pea \\
\hline \multicolumn{2}{|l|}{ Mixed with cereal or potato } \\
\hline Chickpea chip & Chickpea and potato flour \\
\hline
\end{tabular}


Lentil chip

Pea snack with cheese and dill

Chickpea, corn and rice ring

Hummus snack with basil and parsley

Lentil snack with cheese and spices

\section{Others}

Salty banana chip

Seaweed chip
Lentil and potato flour

Rice and pea flour, cheese, dill

Corn, chickpea and rice flour, cheese

Rice and whole chickpea flour, onion, basil, parsley

Whole lentil and rice flour, milk, cheese, spices

Banana

Seaweed, wheat flour 